\title{
Comparison of treatment costs at the Psychiatric Ward in Gryfice between 2016 and 2017, after the introduction of olanzapine long-acting injectable in hospital treatment
}

\author{
Porównanie kosztów leczenia w Oddziale Psychiatrycznym w Gryficach \\ w latach 2016-2017 po wprowadzeniu olanzapiny o przedłużonym uwalnianiu \\ do leczenia szpitalnego
}

Wojciech Herman, Agnieszka Popielewska-Pawłowska

\section{ABSTRACT}

Objectives. The aim of this study was to compare the costs of treatment at the Psychiatric Ward in Gryfice between 2016 and 2017, after the introduction of olanzapine long-acting injectable in hospital treatment.

\footnotetext{
email: wojher@interia.pl
}

Material and methods. Analysis of numerical data of the costs of treatment at the Psychiatric Ward in Gryfice (60 inpatient beds) between 2016 and 2017, data from the central hospital pharmacy - internal expenditure of medicines (OLAI, clozapine and zuclopentixol - acetate and decanoate). In 2016, two patients were treated with olanzapine long-acting injectable; in 2017, it was 25 patients, who met the diagnosis criteria for schizophrenia according to ICD-10 and the indications for the refund of the drug (recurrence of psychotic symptoms as a result of documented persistent lack of cooperation).

Results. Compared with 2016, in 2017, there were 104 fewer patients hospitalised (-7\%); the number of patient-days decreased by $254(-1.1 \%)$ and the number of patients diagnosed as schizophrenia lowered by 32 $(-18.5 \%)$. The cost of pharmacological treatment decreased both per patient (reduction by 6.7\%) and per patient-day (reduction by $12,2 \%)$. The use of other drugs also decreased.

Conclusions. Introduction of olanzapine long-acting injectable in hospital treatment is economically beneficial in the short term. In 2017, as compared to 2016, a reduction in the cost of pharmacological treatment was achieved at the Psychiatric Ward in Gryfice (both per patient and per patient-day). The consumption of other neuroleptic drugs, such as clozapine and zuclopenthixol (acetate and decanoate), decreased, too. 


\section{STRESZCZENIE}

Cel pracy. Celem pracy było porównanie kosztów leczenia w Oddziale Psychiatrycznym w Gryficach w latach 2016-2017 po wprowadzeniu olanzapiny o przedłużonym uwalnianiu (OLAI) do leczenia szpitalnego.

Materiał i metody. Analiza danych liczbowych dotyczących kosztów leczenia w Oddziale Psychiatrycznym SPZZOZ w Gryficach (60-łóżkowy) w latach 2016 i 2017, dane $\mathrm{z}$ apteki szpitalnej - zestawienie rozchodu leków (olanzapina w postaci iniekcji o przedłużonym uwalnianiu, klozapina, zuklopentyksol - octan i dekanian). W 2016 roku leczonych olanzapiną o przedłużonym uwalnianiu było 2 pacjentów, w 2017 roku 25 pacjentów, spełniających kryteria rozpoznania schizofrenii wg ICD-10 oraz wskazania refundacyjne włączenia leku (nawrót objawów psychotycznych w wyniku udokumentowanego, uporczywego braku współpracy).
Wyniki. W porównaniu z rokiem 2016 w roku 2017 było hospitalizowanych o 104 mniej pacjentów (7\%), liczba osobodni była niższa o 254 (1,1\%), a liczba pacjentów leczonych z rozpoznaniem schizofrenii (F20) była mniejsza o $32(18,5 \%)$. Koszty leczenia farmakologicznego zmniejszyły się zarówno w przeliczeniu na pacjenta (redukcja o 6,7\%), jak i osobodzień (redukcja o 12,2\%). Spadło również zużycie innych leków.

Wnioski. Wprowadzenie do leczenia OLAI jest korzystne ekonomicznie w ujęciu krótkoterminowym. W 2017 roku, w porównaniu z 2016 rokiem, uzyskano redukcję kosztów leczenia farmakologicznego w Oddziale Psychiatrycznym w Gryficach (zarówno w przeliczeniu na pacjenta, jak i osobodzień). Zmniejszyło się zużycie innych leków neuroleptycznych - klozapiny oraz zuklopentyksolu (octan i dekanian).

\section{Introduction}

The risk of developing schizophrenia in one's life is estimated at about $1 \%$ and the incidence is estimated at about 15 cases $/ 100,000$ people per year. It is more common in men (the incidence ratio of schizophrenia in men and women is 1.4:1.0). Schizophrenia very rarely occurs below the age of 15 and most often starts in early adulthood. The frequency of so-called late schizophrenia ( $>45$ years) is estimated at about 15\% (Wciórka 2011).

The relatively early onset of schizophrenia means that patients require long-term and comprehensive treatment, multifaceted social support and usually also disability benefits. There are significant direct and indirect individual and social costs involved. In 2009, the National Health Fund allocated nearly PLN 450 million for health services in the treatment of schizophrenia, the largest component was the cost of inpatient care, and ZUS (Polish Social Insurance Institution) expenditure on services related to inability to work of patients with diagnosed schizophrenia was twice as high as the expenditure on patient care (Redakcja Psychiatria 2016). According to estimates, $58 \%$ of patients with schizophrenia are disability pensioners, and less than one fifth (19\%) are professionally active. In the group of hospitalised patients, at least five times as many as $3 / 4$ receive disability benefits and only $7 \%$ continue to work (Kiejna et al. 2014).

Modern pharmacotherapy together with the rehabilitation approach enable to exert a positive effect on the natural course of the disease process, reducing the frequency of recurrences, limiting the risk of intensification of stigmatising deficiency signs, and minimising the somatic consequences of common diseases. Antipsychotics (neuroleptics) are the basis for the treatment of schizophrenia (Jarema 2011). However, long-acting

injectable forms of antipsychotic drugs (LAI, long-acting injections) are nowadays one of the most effective strategies to prevent recurrence of schizophrenia. From the group of 1st generation prolonged-release neuroleptics, zuclopenthixol (zuclopenthixol decanoate), flupentixol (flupentixol decanoate) and haloperidol are available in Poland. In 2003, the first long-acting antipsychotic drug of the second generation (atypical) - risperidone was introduced to the market, in 2009 - paliperidone (Xeplion ${ }^{\circledR}$; administration of the drug every four weeks; in Poland it is reimbursed only from July 2018) and olanzapine (Zypadhera ${ }^{\circledR}$ ), and in 2013 - aripiprazole (Maintena ${ }^{\circledR}$ ). In May 2015, the first antipsychotic LAI drug lasting for 3 months (paliperidone - Invega Trinza ${ }^{\circledR}$ ) was admitted for use in treatment in the United States.

It is estimated that only $7 \%$ of all patients with schizophrenia in Poland are treated with long-acting antipsychotics (January 2015); it is three times more among countries with a similar level of economic development (the Czech Republic and Hungary) and even five to six times more in Scandinavian countries. Atypical neuroleptics constitute less than one third of prolonged-release neuroleptics (Łoza and Murawiec 2015).

The best way to evaluate the effectiveness of LAI is through "mirror study," which compares the course of treatment with the frequency of recurrences in the same patients before and after the starting the LAI therapy over a sufficiently long period of time. First such studies from the 1970s confirmed the advantage of LAI over oral forms of administration (evaluation of the effectiveness of the first typical prolonged-release neuroleptic - fluphenazine enanthate introduced in 1966) (Rzewuska 2012). The Scandinavian study analysed the risk of rehospitalisation of patients with schizophrenia treated, among others, with prolonged-release neuroleptics. 
Between 1972 and 2014, patients were observed for up to 20 years (median: 14.1). It was shown that the use of prolonged-release injectable drugs was associated with a lower risk of rehospitalisation (lower risk in second generation LAI compared to classical LAI) than in oral form of administration (similar dependence - lower risk in atypical oral administration drugs than in classical neuroleptics). Among the antipsychotics used in monotherapy, the lowest risk of rehospitalisation was associated with LAI olanzapine $(\mathrm{HR}=0.46,95 \% \mathrm{CI}=$ $0.36-0.61$ ), clozapine ( $\mathrm{HR}=0.51,95 \% \mathrm{CI}=0.49-0.53$ ) and LAI paliperidone $(\mathrm{HR}=0.51,95 \% \mathrm{CI}=0.40-0.66)$. The risk of psychiatric rehospitalisation with a given oral administration and prolonged-release neuroleptic was also compared - LAI is associated with a lower risk for risperidone, perfenazine (withdrawn from the market in 2013), olanzapine and haloperidol. No significant benefits were found for zuclopenthixol, fluphenazine, flupentixol and aripiprazole (Tiihonen et al. 2018).

Prolonged-release olanzapine is available in three doses (210 mg, $300 \mathrm{mg}$ and $405 \mathrm{mg}$ ). The drug can be used every two or four weeks, depending on the target dose of oral administered olanzapine. Prolonged-release olanzapine is included in the list of reimbursable drugs for the treatment of schizophrenia in adult patients with adequate stabilisation during oral administered olanzapine treatment in the event of recurrence of psychotic symptoms as a result of documented, persistent non-cooperation of the patient.

The main obstacle to a wider use of atypical prolonged-release neuroleptics is undoubtedly the reimbursement criteria, which significantly reduce the possibility of implementing such treatment. For continuously underfunded psychiatric wards, struggling with constant problems, the costs of implementing such treatment are also a significant problem as the administering the drug in tablet form is much cheaper.

The aim of this study is to assess whether a wider introduction of prolonged release olanzapine in the treatment of schizophrenia in a psychiatric ward can be economically beneficial on an annual basis.

\section{Material and methods}

The analysis of numerical data concerning the costs of treatment in the Psychiatric Ward of Independent Public Complex of Health Care Facilities in Gryfice (ward with 60 inpatient beds) between 2016 and 2017 per patient and per person-day was performed. Data from the central pharmacy were used - breakdown of medicine expenditure (prolonged-release olanzapine, zuclopenthixol acetate, zuclopenthixol decanoate, clozapine in dosage of $25 \mathrm{mg}$ and 100).

Between 1 January and 31 December 2016, two patients were treated with prolonged-release olanzapine $(1.2 \%$ among patients with F20; $0.13 \%$ of the total), and between 1 January and 31 December 2017 - 25 patients (18.9\% among patients with $\mathrm{F} 20 ; 1.8 \%$ of the total), meeting the criteria for diagnosis of schizophrenia in accordance with ICD-10 and reimbursement criteria for implementing OLAI (recurrence of psychotic symptoms as a result of documented, persistent lack of cooperation).

\section{Results}

Table 1 presents the number of patients, person-days as well as the number of patients with diagnosed schizophrenia treated in the Psychiatric Ward of Independent Public Complex of Health Care Facilities in Gryfice in 2016 and 2017.

Table 1 Summary of the number of patients and person-days and the number of patients with diagnosed schizophrenia treated between 20162017 at the Psychiatric Ward of Independent Public Complex of Health Care Facilities in Gryfice (source: SPZZOZ in Gryfice)

\begin{tabular}{|lll|}
\hline & $\mathbf{2 0 1 6}$ & $\mathbf{2 0 1 7}$ \\
Number of patients & 1493 & 1389 \\
Number of person-days & 20109 & 19855 \\
F20 & 162 & 132 \\
F20.0 & 135 & 106 \\
F20.1 & 1 & 0 \\
F20.2 & 0 & 0 \\
F20.3 & 10 & 11 \\
F20.4 & 3 & 0 \\
F20.5 & 6 & 8 \\
F20.6 & 1 & 0 \\
F20.8 & 4 & 3 \\
F20.9 & 2 & 4 \\
\hline
\end{tabular}

In 2017, 104 fewer patients (7\%) were hospitalised and 254 fewer person-days (1.1\%) were recorded. The number of treated patients with diagnosed schizophrenia (F20) was $32(18.5 \%)$ lower in 2017.

Table 2 presents the costs of pharmacological treatment per patient and person-day in the Psychiatric Ward of Independent Public Complex of Health Care Facilities in Gryfice in 2016 and 2017.

Table 2 Statement of costs of pharmacological treatment per patient and person-day at the Psychiatric Ward of Independent Public Complex of Health Care Facilities in Gryfice between 2016 and 2017 (source: SPZZOZ in Gryfice)

\begin{tabular}{|llll}
\hline Per patient & 2016 & 2017 & \\
& PLN 75.12 & PLN 70.05 & $\begin{array}{l}\text { PLN -5.07 } \\
(-6.7 \%)\end{array}$ \\
Per person-day & PLN 5.58 & PLN 4.90 & $\begin{array}{l}\text { PLN }-0.68 \\
(-12.2 \%)\end{array}$
\end{tabular}


The analysis showed that the cost of pharmacological treatment per patient decreased from PLN 75.12 in 2016 to PLN 70.05 in 2017 (by PLN 5.07, reduction by 6.7\%); per person-day, it decreased from PLN 5.58 in 2016 to PLN 4.90 in 2017 (by PLN 0.68 , reduction by $12.2 \%$ ).

Table 3 presents the costs of purchase of medicinal products (antibiotics, disinfection, drugs, anaesthetics, narcotic and psychotropic drugs, dressing materials, reagents, liquids, magistral preparations) and drugs (excluding antibiotics, benzodiazepines, anaesthetic drugs, dressing materials, reagents, liquids, magistral preparations) in the Psychiatric Ward of Independent Public Complex of Health Care Facilities in Gryfice in 2016 and 2017.

Table 3 Summary of costs of purchase of medicinal products* and drugs $^{* *}$ in the Psychiatric Ward of Independent Public Complex of Health Care Facilities in Gryfice in 2016 and 2017 (source: SPZZOZ in Gryfice)

\begin{tabular}{|llll}
\hline & 2016 & 2017 & \\
$\begin{array}{l}\text { Medicinal } \\
\text { products* }\end{array}$ & PLN 112,160.27 & PLN 97,298.82 & $\begin{array}{l}\text { PLN -14,861.45 } \\
(-13.3 \%)\end{array}$ \\
Drugs** & PLN 87,917.43 & PLN 71,880.11 & $\begin{array}{l}\text { PLN -16,037.32 } \\
(-18.2 \%)\end{array}$
\end{tabular}

* Medicinal products (antibiotics, disinfection, drugs, anaesthetics, narcotic and psychotropic drugs, dressing materials, reagents, liquids, magistral preparations)

** Drugs (excluding antibiotics, benzodiazepines, anaesthetic drugs, dressing materials, reagents, liquids, magistral preparations)

The costs of purchasing medicinal products (antibiotics, disinfection, drugs, anaesthetics, narcotic and psychotropic drugs, dressing materials, reagents, liquids, magistral preparations) decreased from PLN 112,160.27 in 2016 to PLN 97,298.82 in 2017 (by PLN 14,861.45, cost reduction by $13.3 \%$ ), and the drugs themselves (excluding antibiotics, benzodiazepines, anaesthetic drugs, dressing materials, reagents, liquids, magistral preparations) decreased from PLN 87,917.43 in 2016 to PLN 71,880.11 in 2017 (by PLN 14,861.45, cost reduction by $18.2 \%$ ).

Tables 4-6 show the number of selected neuroleptic drugs purchased (zuclopenthixol acetate and decanoate, clozapine in $25 \mathrm{mg}$ and $100 \mathrm{mg}$ doses) and the cost of their purchase. Table 7 shows the cost of antibiotic therapy used in the Psychiatric Ward of Independent Public Complex of Health Care Facilities in Gryfice in 2016 and 2017.

Table 4 Summary of the number of zuclopenthixol acetate preparations purchased (Clopixol Acuphase $0.05 \mathrm{~g} / \mathrm{ml} ; 1$ package of $5 \mathrm{pcs}$.) and the cost of their purchase in the Psychiatric Ward of Independent Public Complex of Health Care Facilities in Gryfice between 2016 and 2017 (source: SPZZOZ in Gryfice)

\begin{tabular}{|lll}
\hline 2016 & 2017 & \\
64 packages & 50 packages & -14 packages $(-22 \%)$ \\
PLN 4,534.10 & PLN 3,597.16 & PLN -936.94 (-20.7\%)
\end{tabular}

Table 5 Summary of the number of zuclopenthixol decanoate preparations purchased (Clopixol Depot $0.2 \mathrm{~g} / \mathrm{ml} ; 1$ package of $10 \mathrm{pcs}$.) and the cost of their purchase in the Psychiatric Ward of Independent Public Complex of Health Care Facilities in Gryfice between 2016 and 2017 (source: SPZZOZ in Gryfice)

\begin{tabular}{|lll}
\hline 2016 & $\mathbf{2 0 1 7}$ & \\
33 packages & 22 packages & -11 packages $(-33 \%)$ \\
PLN 4,051.63 & PLN 2,715.30 & PLN $-1,336.33(-33 \%)$ \\
\hline
\end{tabular}

Table 6 Summary of the number of purchased clozapine preparations $0.025 \mathrm{~g}$ and $0.1 \mathrm{~g}$ ( 1 package of $50 \mathrm{pcs}$.) and the cost of their purchase in the Psychiatric Ward of Independent Public Complex of Health Care Facilities in Gryfice between 2016 and 2017 (source: SPZZOZ in Gryfice)

\begin{tabular}{|c|c|c|c|}
\hline & 2016 & 2017 & \\
\hline \multirow[t]{2}{*}{$\begin{array}{l}\text { Clozapine } \\
0.025 \mathrm{~g}\end{array}$} & 111 packages & 49.5 packages & $\begin{array}{l}-61.5 \text { packages } \\
(-55.4 \%)\end{array}$ \\
\hline & PLN 1,092.97 & PLN 489.81 & $\begin{array}{l}\text { PLN }-603.16 \\
(-55.2 \%)\end{array}$ \\
\hline \multirow[t]{2}{*}{$\begin{array}{l}\text { Clozapine } \\
0.1 \mathrm{~g}\end{array}$} & 118 packages & 83.5 packages & $\begin{array}{l}-34.5 \text { packages } \\
(-29.2 \%)\end{array}$ \\
\hline & PLN 3,084.77 & PLN 2,196.24 & $\begin{array}{l}\text { PLN -888.53 } \\
(-28.8 \%)\end{array}$ \\
\hline
\end{tabular}

Table 7 Statement of costs of antibiotic therapy in the Psychiatric Ward of Independent Public Complex of Health Care Facilities in Gryfice between 2016 and 2017 (source: SPZZOZ in Gryfice)

\begin{tabular}{|lll}
\hline 2016 & 2017 & \\
PLN 2,881.64 & PLN 2,003.90 & PLN -877.74 (-30.5\%)
\end{tabular}

The use of zuclopenthixol - acetate by $22 \%$ (generating savings of PLN 936.94) and decanoate by $33 \%$ (generating savings of PLN 1,336.33) was reduced. The consumption of clozapine decreased (in the $25 \mathrm{mg}$ dose by $55.4 \%$ - generating savings of PLN 603.16 and $100 \mathrm{mg}$ by $29.2 \%$ generating savings of PLN 888.53). The cost of antibiotic therapy was reduced by PLN 877.74 (30.5\%).

\section{Overview}

In 2017, in the Psychiatric Ward of Independent Public Complex of Health Care Facilities in Gryfice (Zachodniopomorskie Province), olanzapine in the form of LAI was introduced into the hospital's formulary, thus enabling its broad implementation into the treatment of patients with schizophrenia. In 2017, a total of 83 packages of Zypadhera preparation were purchased (mainly in the dose of $300 \mathrm{mg}$, which corresponds to the oral dose of $20 \mathrm{mg} / \mathrm{d}$ ) - the cost amounted to PLN 18,160.09; in 2016, olanzapine in the form of LAI was used to treat only two patients. The numerical data presented in the publication 
are converted into units (per patient or a person-day), no summary values are given. Clinical experience shows that patients hospitalised, e.g. because of complications of addiction, often generate much higher unit costs, require the supply of many additional drugs or a number of diagnostic tests.

Comparing 2017 to 2016, it was found that the costs of pharmacological treatment both per patient and per person-day decreased significantly (by $6.8 \%$ and $12.2 \%$, respectively). Taking into account the cost reduction per patient and per person-day, it may be hypothesised that this may have been related to a wider introduction of prolonged-release olanzapine to treatment of patients with schizophrenia.

Moreover, the costs of purchase of both medicinal products (antibiotics, disinfection, drugs, anaesthetics, narcotic and psychotropic drugs, dressing materials, reagents, liquids, magistral preparations) decreased by more than $13 \%$ and drugs (excluding antibiotics, benzodiazepines, anaesthetic drugs, dressing materials, reagents, liquids, magistral preparations) by almost one-fifth (18.2\%). In addition to a possible link to a wider introduction of prolonged-release olanzapine, this reduction may be related to a fewer number of hospitalised patients.

It is worth noting that since 2017 in the Psychiatric Ward of Independent Public Complex of Health Care Facilities in Gryfice, there has been a Rehabilitation Sub-Department, which in certain clinical conditions makes it possible to extend the hospitalisation period, and thereby, with a $7 \%$ decrease in the number of patients, the number of person-days was lower only by $1.1 \%$. Analysing the expenditure of respective drugs, the use of zuclopenthixol preparations (both acetate - by more than one fifth and decanoate - by almost one third) decreased significantly, generating over PLN 2,000 of savings in total. The change is undoubtedly beneficial for patients; in many cases, the treatment was modified from typical to atypical prolonged-release neuroleptic. It is worth noting that the consumption of clozapine has been significantly reduced (in both $25 \mathrm{mg}$ and $100 \mathrm{mg}$ doses), especially in the case of the smaller dose, which indicates a lesser need to include this neuroleptic in the treatment. The lower expenditure of clozapine also affects other costs of hospitalisation of patients - the number of laboratory tests performed is decreasing (control peripheral blood morphology initially once a week, then once a month). It is worth noting that the costs of antibiotic therapy are significantly lowered - by almost a third. The number of patients in severe somatic condition requiring further treatment in other wards (mainly in the internal medicine ward) was at a similar level (17 patients in 2016 and 18 patients in 2017). The policy on the use of antibiotic therapy has not changed during the analysed years. Could a wider implementation of prolonged-release olanzapine treatment be one of the factors? It is known that lower drug sedation and shorter hospitalisation time of patients with schizophrenia may minimise the risk of complications requiring antibiotic therapy.

A French study published in 2018 analysed, among other things, the cost of hospitalisation and the number of outpatient visits per year for patients which treatment included prolonged-release olanzapine $(\geq 210 \mathrm{mg}$ every 4 weeks for at least 1 year). The study included adult patients meeting the criteria for diagnosis of schizophrenia or schizoaffective disorder according to DSM-IV in whom no improvement was achieved despite the use of at least two different antipsychotics in appropriate doses for at least 6 weeks. Out of the 136 patients who were treated with prolonged-release olanzapine between January 2013 and January 2018, 40 were qualified for the study; the main reasons for exclusion were OLAI treatment duration of less than one year or discontinuation of treatment. In the group of patients qualified for the study, almost one third (32.5\%) were previously treated with clozapine and one in four patients was treated with seismotherapy. The annual average cost of hospital treatment was EUR $48.024 \pm 43.434$ in the period before the LAI olanzapine treatment was implemented and EUR 6,603 $\pm 13,066$ after starting the OLAI treatment, i.e. a reduction in hospitalisation costs of $86.2 \%$ was achieved. This is the first study to provide evidence of a reduction in the cost of hospital services following the implementation of prolonged-release olanzapine treatment. The authors of the publication emphasise the necessity of careful interpretation of the results due to the small size of the studied group and broad selection criteria (Fefeu et al. 2018).

To date, there are no Polish studies analysing the costs of hospital services after the implementation of OLAI treatment, or more broadly neuroleptics with prolonged release.

\section{Conclusions}

After the analysis of the costs of treatment with prolonged-release olanzapine in the Psychiatric Ward of Independent Public Complex of Health Care Facilities in Gryfice, economic benefits per annum can be observed as well as reduction of drug expenditures despite the fact that the unit price of the drug is many times higher (LAI olanzapine compared to oral administered olanzapine). First of all, the benefits for patients from the implementation of modern treatment are important - lower risk of recurrences and a chance for broadly understood functional improvement. 


\section{Wstęp}

Ryzyko zachorowania na schizofrenię w ciągu życia jest oceniane na około 1\%, a zapadalność szacowana jest na około 15 przypadków/100 000 osób rocznie. Częściej chorują mężczyźni (proporcja częstości występowania schizofrenii u mężczyzn i kobiet wynosi 1,4:1,0). Schizofrenia bardzo rzadko występuje u osób poniżej 15. roku życia, a najczęściej rozpoczyna się w okresie wczesnej dorosłości. Częstość tzw. schizofrenii późnej (> 45. roku życia) szacowana jest na około 15\% (Wciórka 2011).

Względnie wczesny początek schizofrenii sprawia, że chorzy wymagają długotrwałego i kompleksowego leczenia, wielopłaszczyznowego oparcia społecznego, zwykle równieź świadczeń związanych z niepełnosprawnością. Wiążą się z tym znaczne, bezpośrednie i pośrednie, koszty indywidualne i społeczne. W 2009 roku Narodowy Fundusz Zdrowia przeznaczył na świadczenia zdrowotne w leczeniu schizofrenii prawie $450 \mathrm{mln}$ zł, największą składową był koszt opieki stacjonarnej, a wydatki Zakładu Ubezpieczeń Społecznych (ZUS) na świadczenia związane z niezdolnością do pracy chorych na schizofrenię dwukrotnie przewyższały wydatki NFZ na świadczenia opieki nad pacjentami (Redakcja Psychiatria 2016). Według szacunków $58 \%$ pacjentów chorujących na schizofrenię to renciści, mniej niż 1/5 (19\%) jest czynna zawodowo. W grupie pacjentów hospitalizowanych przynajmniej pięciokrotnie aż 3/4 pobiera świadczenie rentowe, a zaledwie $7 \%$ dalej pracuje (Kiejna i wsp. 2014).

Nowoczesna farmakoterapia wraz z podejściem rehabilitacyjnym umożliwiają wywieranie korzystnego wpływu na naturalny przebieg procesu chorobowego, redukując częstość nawrotów, ograniczając ryzyko nasilania się stygmatyzujących objawów ubytkowych oraz minimalizując konsekwencje somatyczne chorób współwystępujących. Leki przeciwpsychotyczne (neuroleptyki) są podstawą leczenia schizofrenii (Jarema 2011). Długodziałające postacie iniekcyjne leków przeciwpsychotycznych (LAI, long-acting injections) stanowią dziś natomiast jedną z najefektywniejszych strategii przeciwdziałania nawrotom schizofrenii. Z grupy neuroleptyków o przedłużonym uwalnianiu I generacji w Polsce dostępne są zuklopentyksol (dekanian zuklopentyksolu), flupentyksol (dekanian flupentyksolu) oraz haloperidol. W 2003 roku wprowadzono na rynek pierwszy lek przeciwpsychotyczny długodziałający II generacji (atypowy) - risperidon, w 2009 roku - paliperidon (Xeplion ${ }^{\circledR}$; podaż leku raz na cztery tygodnie; w Polsce objęty refundacją dopiero od lipca 2018) i olanzapinę (Zypadhera ${ }^{\circledR}$ ), a w 2013 roku - aripiprazol (Maintena ${ }^{\circledR}$ ). W maju 2015 roku dopuszczono do leczenia w Stanach Zjednoczonych pierwszy lek przeciwpsychotyczny w postaci LAI działający przez 3 miesiące (paliperidon - Invega Trinza ${ }^{\circledR}$ ).

Najlepszą metodą oceny skuteczności stosowania LAI są „badania lustrzane” (mirror study), polegają na porównywaniu przebiegu leczenia i częstości nawrotów psychozy u tych samych pacjentów w okresie przed i po włączeniu terapii LAI, w odpowiednio długiej perspektywie. Już pierwsze tego typu badania z lat 70. XX wieku potwierdziły przewagę LAI nad postaciami doustnymi (ocena skuteczności pierwszego typowego neuroleptyku o przedłużonym uwalnianiu - wprowadzony w 1966 roku enantan flufenazyny) (Rzewuska 2012). W skandynawskim badaniu analizowano ryzyko rehospitalizacji pacjentów chorujących na schizofrenię, leczonych m.in. neuroleptykami o przedłużonym uwalnianiu. Czas obserwacji pacjentów w latach 1972-2014 wynosił do 20 lat (mediana 14,1 roku). Wykazano, że stosowanie leków w formie iniekcji o przedłużonym uwalnianiu wiązało się z niższym ryzykiem rehospitalizacji (niższe ryzyko wśród LAI II generacji w porównaniu z LAI klasycznymi) niż leków w formie doustnej (podobna zależność - niższe ryzyko wśród doustnych leków atypowych niż neuroleptyków klasycznych). Z leków przeciwpsychotycznych stosowanych w monoterapii najniższe ryzyko rehospitalizacji wiązało się z zastosowaniem olanzapiny LAI $(\mathrm{HR}=0,46,95 \% \mathrm{CI}=0,36-0,61)$, klozapiny $(\mathrm{HR}=0,51,95 \% \mathrm{CI}=0,49-0,53)$ i paliperidonu LAI ( $\mathrm{HR}=0,51,95 \% \mathrm{CI}=0,40-0,66)$. Porównano również ryzyko rehospitalizacji psychiatrycznej przy zastosowaniu danego neuroleptyku w formie doustnej i o przedłużonym uwalnianiu - LAI wiąże się z niższym ryzykiem w przypadku risperidonu, perfenazyny (wycofana z rynku w 2013 roku), olanzapiny i haloperidolu; nie stwierdzono istotnych korzyści w przypadku zuklopentyksolu, flufenazyny, flupentiksolu i aripiprazolu (Tiihonen i wsp. 2018).

Olanzapina o przedłużonym uwalnianiu jest dostępna w trzech dawkach (210 mg, 300 mg, 405 mg). Lek można stosować co 2 lub 4 tygodnie - w zależności od ustalonej docelowej dawki olanzapiny w formie doustnej. Olanzapina o przedłużonym uwalnianiu znajduje się na liście leków refundowanych ze wskazaniem w leczeniu schizofrenii u dorosłych pacjentów, u których uzyskano odpowiednią stabilizację podczas leczenia olanzapiną w postaci doustnej, w przypadku nawrotu objawów psychotycznych w wyniku udokumentowanego, uporczywego braku współpracy chorego.

Główną przeszkodą do szerszego zastosowania neuroleptyków atypowych o przedłużonym uwalnianiu są niewątpliwie wskazania refundacyjne, znacznie zawężające możliwość włączenia takiego leczenia. Dla wciąż niedofinansowanych, borykających się z ciągłymi problemami oddziałów psychiatrycznych, istotnym problem są również koszty wdrożenia takiego leczenia, gdyż dużo tańsza jest podaż leku w formie tabletkowej.

Celem niniejszej pracy jest ocena, czy szersze wprowadzenie olanzapiny o przedłużonym uwalnianiu w leczeniu chorych na schizofrenię w oddziale psychiatrycznym może być ekonomicznie korzystne w okresie rocznym. 


\section{Materiał i metody}

Dokonano analizy danych liczbowych dotyczących kosztów leczenia w Oddziale Psychiatrycznym SPZZOZ w Gryficach (oddział 60-łóżkowy) w latach 2016-2017 w przeliczeniu na pacjenta i osobodzień. Wykorzystano dane $\mathrm{z}$ apteki centralnej - zestawienie rozchodu leków (olanzapina o przedłużonym uwalnianiu, octan zuklopentyksolu, dekanian zuklopentyksolu, klozapina w dawcach 25 mg i 100).

W okresie 1.01-31.12.2016 roku leczonych olanzapiną o przedłużonym uwalnianiu było 2 pacjentów (1,2\% wśród chorych z F20; 0,13\% ogółu), a w okresie 1.01-31.12.2017 roku - 25 pacjentów (18,9\% wśród chorych z F20; 1,8\% ogółu), spełniających kryteria rozpoznania schizofrenii wg ICD-10 oraz wskazania refundacyjne włączenia OLAI (nawrót objawów psychotycznych w wyniku udokumentowanego, uporczywego braku współpracy).

\section{Wyniki}

W tabeli 1 zestawiono zarówno liczbę pacjentów, osobodni, jak i liczbę pacjentów z rozpoznaniem schizofrenii leczonych w Oddziale Psychiatrycznym SPZZOZ w Gryficach w latach 2016 i 2017.

Tabela 1 Zestawienie liczby pacjentów i osobodni oraz liczby pacjentów leczonych z rozpoznaniem schizofrenii w latach 2016-2017 w Oddziale Psychiatrycznym SPZZOZ w Gryficach (źródło: SPZZOZ w Gryficach)

\begin{tabular}{|lll}
\hline & $\mathbf{2 0 1 6}$ & $\mathbf{2 0 1 7}$ \\
Liczba pacjentów & 1493 & 1389 \\
Liczba osobodni & 20109 & 19855 \\
F20 & 162 & 132 \\
F20.0 & 135 & 106 \\
F20.1 & 1 & 0 \\
F20.2 & 0 & 0 \\
F20.3 & 10 & 11 \\
F20.4 & 3 & 0 \\
F20.5 & 6 & 8 \\
F20.6 & 1 & 0 \\
F20.8 & 4 & 3 \\
F20.9 & 2 & 4
\end{tabular}

W roku 2017 było hospitalizowanych o 104 mniej pacjentów (7\%), liczba osobodni była niższa o 254 (1,1\%). Liczba pacjentów leczonych z rozpoznaniem schizofrenii (F20) była niższa w 2017 roku o 32 (18,5\%).

W tabeli 2 zestawiono koszty leczenia farmakologicznego w przeliczeniu na pacjenta oraz osobodzień w Oddziale Psychiatrycznym SPZZOZ w Gryficach w latach 2016 i 2017.
Tabela 2 Zestawienie kosztów leczenia farmakologicznego w przeliczeniu na pacjenta oraz osobodzień w Oddziale Psychiatrycznym SPZZOZ w Gryficach w latach 2016 i 2017 (Źródło: SPZZOZ w Gryficach)

\begin{tabular}{|llll|}
\hline & $\mathbf{2 0 1 6}$ & $\mathbf{2 0 1 7}$ & \\
Na pacjenta & $75,12 \mathrm{zł}$ & $70,05 \mathrm{zł}$ & $\begin{array}{l}-5,07 \mathrm{zł} \\
(-6,7 \%)\end{array}$ \\
& & & $-0,68 \mathrm{zł}$ \\
Na osobodzień & $5,58 \mathrm{zł}$ & $4,90 \mathrm{zł}$ & $(-12,2 \%)$
\end{tabular}

Wyniki analizy wykazały, że koszty leczenia farmakologicznego w przeliczeniu na pacjenta zmniejszyły się z 75,12 zł w 2016 roku do 70,05 zł w 2017 roku (o 5,07 zł, redukcja o 6,7\%), w przeliczeniu na osobodzień spadły z 5,58 zł w 2016 roku do 4,90 zł w 2017 roku (o 0,68 zł, redukcja o $12,2 \%)$.

W tabeli 3 zestawiono koszty zakupu produktów leczniczych (antybiotyki, dezynfekcja, leki, leki anestetyczne, leki odurzające i psychotropowe, materiał opatrunkowy, odczynnik, płyny, receptura) oraz leków (z wyłączeniem antybiotyków, benzodiazepin, leków anestetycznych, materiałów opatrunkowych, odczynników, płynów, leków recepturowych) w Oddziale Psychiatrycznym SPZZOZ w Gryficach w latach 2016 i 2017.

Tabela 3 Zestawienie kosztów zakupu produktów leczniczych* oraz leków** w Oddziale Psychiatrycznym SPZZOZ w Gryficach w latach 2016 i 2017 (Źródło: SPZZOZ w Gryficach)

\begin{tabular}{|llll|}
\hline & 2016 & 2017 & \\
$\begin{array}{l}\text { Produkty } \\
\text { lecznicze* }\end{array}$ & 112160,27 zł & 97298,82 zł & $\begin{array}{l}-14861,45 \text { zł } \\
(-13,3 \%)\end{array}$ \\
Leki** $^{*}$ & 87917,43 zł & 71880,11 zł & $\begin{array}{l}-16037,32 \text { zł } \\
(-18,2 \%)\end{array}$
\end{tabular}

* Produkty lecznicze (antybiotyki, dezynfekcja, leki, leki anestetyczne, leki odurzające i psychotropowe, materiał opatrunkowy, odczynnik, płyny, receptura)

** Leki (z wyłączeniem antybiotyków, benzodiazepin, leków anestetycznych, materiałów opatrunkowych, odczynników, płynów, leków recepturowych)

Koszty zakupu produktów leczniczych (antybiotyki, dezynfekcja, leki, leki anestetyczne, leki odurzające i psychotropowe, materiał opatrunkowy, odczynnik, płyny, receptura) zmniejszyły się ze 112 160,27 zł w 2016 roku do 97298,82 zł w 2017 roku (o 14 861,45 zł, redukcja kosztów o 13,3\%), a samych leków (z wyłączeniem antybiotyków, benzodiazepin, leków anestetycznych, materiałów opatrunkowych, odczynników, płynów, leków recepturowych) z 87 917,43 zł w 2016 roku do 71 880,11 zł w 2017 roku (o 16 037,32 zł, redukcja kosztów o 18,2\%).

W tabelach 4-6 zestawiono liczbę zakupionych wybranych leków neuroleptycznych (octan i dekanian zuklopentyksolu, klozapina w dawkach $25 \mathrm{mg}$ i $100 \mathrm{mg}$ ) oraz koszt ich zakupu, w tabeli 7 zestawiono koszt zastosowanej antybiotykoterapii w Oddziale Psychiatrycznym SPZZOZ w Gryficach w latach 2016 i 2017. 
Tabela 4 Zestawienie liczby zakupionych preparatów octanu zuklopentyksolu (Clopixol Acuphase $0,05 \mathrm{~g} / \mathrm{ml} ; 1$ op. a 5 szt.) oraz koszt ich zakupu w Oddziale Psychiatrycznym SPZZOZ w Gryficach w latach 2016 i 2017 (Źródło: SPZZOZ w Gryficach)

\begin{tabular}{|lll}
\hline 2016 & 2017 & \\
64 op. & 50 op. & -14 op. $(-22 \%)$ \\
4534,10 zł & 3597,16 zł & $-936,94$ zł $(-20,7 \%)$ \\
\hline
\end{tabular}

Tabela 5 Zestawienie liczby zakupionych preparatów dekanianu zuklopentyksolu (Clopixol Depot 0,2 g/ml; 1 op. a 10 szt.) oraz koszt ich zakupu w Oddziale Psychiatrycznym SPZZOZ w Gryficach w latach 2016 i 2017 (Źródło: SPZZOZ w Gryficach)

\begin{tabular}{|lll}
\hline 2016 & 2017 & \\
33 op. & 22 op. & -11 op. $(-33 \%)$ \\
4051,63 zł & 2715,30 zł & $-1336,33$ zł $(-33 \%)$ \\
\hline
\end{tabular}

Tabela 6 Zestawienie liczby zakupionych preparatów klozapiny $0,025 \mathrm{~g}$ i 0,1 g (1 op. a 50 szt.) oraz koszt ich zakupu w Oddziale Psychiatrycznym SPZZOZ w Gryficach w latach 2016 i 2017 (Źródło: SPZZOZ w Gryficach)

\begin{tabular}{|llll}
\hline & $\mathbf{2 0 1 6}$ & $\mathbf{2 0 1 7}$ & \\
Klozapina & 111 op. & 49,5 op. & $-61,5$ op. $(-55,4 \%)$ \\
$0,025 \mathrm{~g}$ & & & \\
& $1092,97 \mathrm{zł}$ & 489,81 zł & $-603,16$ zł $(-55,2 \%)$ \\
Klozapina & 118 op. & 83,5 op. & $-34,5$ op. $(-29,2 \%)$ \\
$0,1 \mathrm{~g}$ & & & \\
& 3084,77 zł & 2196,24 zł & $-888,53$ zł $(-28,8 \%)$
\end{tabular}

Tabela 7 Zestawienie kosztów antybiotykoterapii w Oddziale Psychiatrycznym SPZZOZ w Gryficach w latach 2016 i 2017 (Źródło: SPZZOZ w Gryficach)

\begin{tabular}{|lll}
\hline 2016 & 2017 & \\
2881,64 zł & 2003,90 zł & $-877,74$ zł $(-30,5 \%)$
\end{tabular}

Zmniejszyło się zastosowanie preparatów zuklopentyksolu - octanu o $22 \%$ (generując oszczędności w kwocie 936,94 zł) i dekanianu o 33\% (generując oszczędności w kwocie 1336,33 zł). Zmniejszyło się zużycie klozapiny (w dawce 25 mg o 55,4\% - generując oszczędności w kwocie 603,16 zł oraz $100 \mathrm{mg}$ o $29,2 \%$ - generując oszczędności w kwocie 888,53 zł). Koszt antybiotykoterapii uległ redukcji o $877,74 \mathrm{zł}$ (o $30,5 \%$ ).

\section{Omówienie}

W 2017 roku w Oddziale Psychiatrycznym SPZZOZ w Gryficach (województwo zachodniopomorskie) olanzapina w formie LAI została wprowadzona do receptariusza szpitalnego, tym samym umożliwiło to wreszcie jej szerokie wdrożenie do leczenia pacjentów ze schizofrenią.
W 2017 roku zakupiono łącznie 83 opakowania preparatu Zypadhera (głównie w dawce 300 mg, co odpowiada dawce doustnej 20 mg/d) - koszt wyniósł 18 160,09zł; w 2016 roku olanzapina $w$ formie LAI była stosowana w leczeniu zaledwie 2 pacjentów. Prezentowane w publikacji dane liczbowe przeliczone są jednostkowo (na pacjenta lub osobodzień), nie są podawane wartości sumaryczne. $\mathrm{Z}$ doświadczenia klinicznego wiadomo, że pacjenci hospitalizowani np. z powodu powikłań uzależnienia często generują dużo wyższe koszty jednostkowe, wymagają podaży wielu leków dodatkowych czy przeprowadzenia szeregu badań diagnostycznych.

Porównując rok 2017 z 2016 stwierdzono, że koszty leczenia farmakologicznego zarówno w przeliczeniu na pacjenta, jak i osobodzień istotnie spadły (odpowiednio o 6,8\% i 12,2\%). Biorąc pod uwagę redukcję kosztów w przeliczeniu na pacjenta oraz na osobodzień można postawić hipotezę, że mogło to mieć związek z szerszym wprowadzeniem olanzapiny o przedłużonym uwalnianiu do leczenia chorych na schizofrenię.

Oprócz tego znacznie spadły koszty zakupu zarówno produktów leczniczych (antybiotyki, dezynfekcja, leki, leki anestetyczne, leki psychotropowe, materiał opatrunkowy, odczynnik, płyny, receptura) - o ponad $13 \%$, a samych leków (z wyłączeniem antybiotyków, benzodiazepin, leków anestetycznych, materiałów opatrunkowych, odczynników, płynów, leków recepturowych) prawie o 1/5 (18,2\%). Obok ewentualnego związku z szerszym wprowadzeniem olanzapina o przedłużonym uwalnianiu redukcja ta może mieć związek z mniejszą liczbą hospitalizowanych pacjentów.

Warto zaznaczyć, że od 2017 roku w Oddziale Psychiatrycznym SPZZOZ w Gryficach funkcjonuje Pododdział Rehabilitacyjny - w określonych stanach klinicznych umożliwiający wydłużenie okresu hospitalizacji, stąd przy spadku liczby pacjentów o 7\% liczba osobodni była niższa tylko o 1,1\%. Analizując zużycie poszczególnych leków - znacznie zmniejszyło się zastosowanie preparatów zuklopentyksolu (zarówno octanu - o ponad 1/5 jak i dekanianu - o prawie 1/3); generując łącznie ponad 2 tysiące zł oszczędności. Zmiana jest przede wszystkim niewątpliwie korzysta dla pacjentów, w wielu wypadkach dokonano modyfikacji leczenia $\mathrm{z}$ neuroleptyku typowego na atypowy o przedłużonym uwalnianiu. Zwraca uwagę znaczne zmniejszenie zużycia klozapiny (zarówno w dawkach 25 mg i 100 mg) - szczególnie mniejszej dawki, co wskazuje na rzadszą konieczność włączania tego neuroleptyku do leczenia. Mniejsze zużycie klozapiny wpływa również na inne koszty hospitalizacji pacjentów - spada liczba wykonywanych badań laboratoryjnych (kontrolna morfologia krwi obwodowej początkowo raz na tydzień, następnie raz na miesiąc). Uwagę zwraca znaczny spadek kosztów antybiotykoterapii - prawie o 1/3. Liczba pacjentów w ciężkim stanie somatycznym, wymagających przekazania do dalszego leczenia w innych oddziałach (głównie w oddziale chorób 
wewnętrznych), była na zbliżonym poziomie (w 2016 roku 17 pacjentów, a w 2017 roku 18 pacjentów). Polityka w zakresie stosowania antybiotykoterapii nie uległa na przestrzeni analizowanych lat zmianie. Czy wdrożenie na szerszą skalę leczenia olanzapiną o przedłużonym uwalnianiu mogło być jednym z czynników? Wiadomo, że mniejsza sedacja polekowa i skrócony czas hospitalizacji pacjentów ze schizofrenią mogą minimalizować ryzyko powikłań wymagających włączenia antybiotykoterapii.

W opublikowanym w 2018 roku badaniu francuskim analizowano m.in. koszty hospitalizacji i liczbę wizyt ambulatoryjnych w ciągu roku pacjentów, u których wdrożono leczenie olanzapiną o przedłużonym uwalnianiu ( $\geq 210 \mathrm{mg}$ co 4 tygodnie przez co najmniej rok). Do badania włączono pacjentów pełnoletnich, spełniających kryteria rozpoznania schizofrenii lub zaburzenia schizoafektywnego wg DSM-IV, u których nie uzyskano poprawy pomimo stosowania przynajmniej dwóch różnych leków przeciwpsychotycznych w odpowiednich dawkach przez minimum 6 tygodni. Spośród 136 pacjentów, którzy między styczniem 2013 a styczniem 2018 roku, byli leczeni olanzapiną o przedłużonym uwalnianiu do badania zakwalifikowano 40 - głównymi przyczynami wykluczenia były czas leczenia OLAI krótszy niż rok lub przerwanie leczenia. W grupie zakwalifikowanych do badania pacjentów prawie 1/3 (32,5\%) była wcześniej leczona klozapiną, a u co czwartego pacjenta stosowano

Conflict of interest was not declared. / Nie zgłoszono konfliktu interesów.

The work described in this article has been carried out in accordance with The Code of Ethics of the World Medical Association (Declaration of Helsinki) for experiments involving humans, EU Directive 2010/63/EU for animal experiments, and Uniform Requirements for manuscripts submitted to biomedical journals. / Treści przedstawione $w$ artykule są zgodne z zasadami Deklaracji Helsińskiej, dyrektywami EU oraz ujednoliconymi wymaganiami dla czasopism biomedycznych.

Authors' contributions / Wkład autorów: WH - core contribution to the concept and design of the paper, data interpretation, preparation of the bibliography / zasadniczy wkład w koncepcję i projekt pracy, interpretacja danych, zebranie piśmiennictwa; AP-P - data collection, preparation of results for analysis, work review / zebranie danych, przygotowanie wyników do analizy, zrecenzowanie pracy.

\section{References / Piśmiennictwo}

1. Fefeu M, De Maricourt P, Cachia A, Hoertel N, Vacheron M, Wehbe E. et al. One-year mirror-image study of the impact of olanzapine long-acting injection on healthcare resource utilisation and costs in severe schizophrenia. Psychiatry Res 2018; 270: 205-210.

2. Jarema M, Rabe-Jabłońska J. Schizofrenia. In: Standardy leczenia farmakologicznego niektórych zaburzeń psychicznych. Jarema M. (ed.). Via medica. Gdańsk 2011, 1-46. sejsmoterapię. Roczne średnie koszty świadczeń szpitalnych wyniosły 48,024 $\pm 43,434$ euro w okresie przed wdrożeniem leczenia olanzapiną LAI i $6603 \pm 13066$ euro po rozpoczęciu leczenia OLAI, tj. uzyskano redukcję kosztów hospitalizacji o $86,2 \%$. Jest to pierwsze badanie dostarczające dowodów na zmniejszenie kosztów świadczeń szpitalnych po wdrożeniu leczenia olanzapiną o przedłużonym uwalnianiu. Autorzy publikacji podkreślają konieczność ostrożnej interpretacji wyników z uwagi na niewielką liczebność badanej grupy i szerokie kryteria kwalifikacji (Fefeu i wsp. 2018).

Do dziś brak jest polskich badań analizujących koszty świadczeń szpitalnych po wdrożeniu leczenia OLAI, czy szerzej neuroleptykami o przedłużonym uwalnianiu.

\section{Wnioski}

Po analizie kosztów leczenia olanzapiną o przedłużonym uwalnianiu w Oddziale Psychiatrycznym SPZZOZ w Gryficach można stwierdzić korzyści ekonomiczne w skali rocznej, zmniejszenie wydatków na leki pomimo wielokrotnie wyższej ceny jednostkowej leku (olanzapina LAI w porównaniu z olanzapiną doustną). Przede wszystkim istotne są korzyści dla pacjentów $\mathrm{z}$ wdrożenia nowoczesnego leczenia - mniejsze ryzyko nawrotów choroby oraz szansa na szeroko pojętą poprawę funkcjonalną.

3. Kiejna A, Piotrowski P, Adamowski T. (eds.): Raport Schizofrenia. Perspektywa społeczna. Sytuacja w Polsce. 2014; https://www.janssen.com/poland/sites/www_janssen_ com_poland/files/raport_schizofrenia_perspektywa_spoleczna._sytuacja_w_polsce.pdf.

4. Łoza B, Murawiec S. Leki przeciwpsychotyczne w postaci długodziałających iniekcji w leczeniu schizofrenii - nowe standardy terapii. Psychiatria 2015; 12,3: 119-127.

5. Redakcja Psychiatria: Schizofrenia - leki długodziałające dają szansę na poprawę jakości życia chorych i ich opiekunów. Psychiatria 2016; 13,2: 116-120.

6. Rzewuska M. Leki przeciwpsychotyczne. In: Psychiatria, t. III. Wciórka J, Pużyński S, Rybakowski J. (eds.). Edra Urban \& Partner. Wrocław 2012; 13-17, 25-27.

7. Taipale H, MehtäläJ, Tanskanen A, Tiihonen J. Comparative Effectiveness of Antipsychotic Drugs for Rehospitalization in Schizophrenia - A Nationwide Study With 20-Year Follow-up. Schizophrenia Bulletin 2018; 44: 1381-1387.

8. Wciórka J. Psychozy schizofreniczne, zaburzenia schizotypowe i schizoafektywne. In: Psychiatria, t. II. Pużyński S, Rybakowski J, Wciórka J. (eds.). Edra Urban \& Partner. Wrocław 2011; 195-207.

9. Wiela-Hojeńska A, Rymaszewska J. O postępach psychofarmakoterapii. W: Psychiatria w medycynie, t. III. Rymaszewska J., Dudek D. (eds.). Medical education. Warszawa 2018; 185-193.

10. Zypadhera - charakterystyka produktu leczniczego [https:// ec.europa.eu/health/documents/communityregister/2011/ 20111020111671/anx_111671_pl.pdf]. 